\title{
Species identification of Legionella via intergenic 16S-23S ribosomal spacer PCR analysis
}

\author{
Serge Riffard, ${ }^{1}$ François Lo Presti, ${ }^{1}$ Philippe Normand, ${ }^{2}$ Françoise Forey, ${ }^{1}$ \\ Monique Reyrolle, ${ }^{1}$ Jerome Etienne ${ }^{1}$ and François Vandenesch ${ }^{1}$
}

1 Centre National de Référence des Legionella, UPRES EA1655, Faculté de Médecine R. T. H. Laënnec, rue Guillaume Paradin, 69372 Lyon Cedex 08, France

2 Laboratoire d'Ecologie Microbienne du Sol, UMR CNRS 5557, Université Claude Bernard Lyon I, 43 Boulevard du 11

Novembre 1918, 69622

Villeurbanne cedex, France
Author for correspondence: Serge Riffard. Tel: +33 4787786 57. Fax: +33478 778658 . e-mail: derba@cimac-res.univ-lyon1.fr

\begin{abstract}
Species identification of Legionella in routine laboratory testing is hampered by the lack of highly discriminatory phenotypic tests. Amplification polymorphism of the intergenic 16S-23S spacer regions (ISR) has been previously developed for identification of species within the Legionellaceae [Hookey, J. V., Birtles, R. J. \& Saunders, N. A. (1995). J Clin Microbiol 33, 2377-2381], but it did not provide enough resolution to distinguish all members of the bluish-white autofluorescent species and the red autofluorescent group of the Legionellaceae. By choosing new primers that target regions 4 (positions 1521-1541 of Escherichia coli 16S rRNA gene) and 6 (positions 114-132 of E. coli 23S rRNA gene) within the rDNA operon close to the 165-23S intergenic spacer, 34 profiles were determined among the 79 type and reference strains representing 42 species that were tested. Analysis of the RFLP generated after HinfI restriction digestion of the PCR products further improved the method, allowing complete discrimination among the species and subspecies of Legionella tested. Twenty-three well-identified strains from unrelated origins belonging to seven species gave amplification patterns identical to that of their type strain. The technique was also tested on $\mathbf{8 0}$ field isolates that could not be unequivocally assigned to groups by phenotypic methods. Seventy-two per cent $(58 / 80)$ of these isolates had a profile identical to that of a type strain, while $27 \%(22 / 80)$ may correspond to new taxa since their ISR-PCR profiles did not match any of the known profiles.
\end{abstract}

Keywords: Legionellaceae, 16S-23S intergenic spacer, ISR-PCR

\section{INTRODUCTION}

The genus Legionella is represented at the present time by 42 species $(2,10)$. The recognition of Legionella species is based on the study of classical phenotypic traits including growth characteristics, biochemical reactivity and direct fluorescent antibodies typing (DFA) (19). However, these methods do not allow differentiation of all species and $16 \mathrm{~S}$ rDNA sequencing (10) or DNA-DNA hybridization (3) are sometimes

\footnotetext{
Abbreviations: AP-PCR, arbitrarily primed PCR; DFA, direct fluorescent antibodies; ISR, intergenic 16S-23S spacer region; RAPD, random amplified polymorphic DNA.

The GenBank accession numbers for the sequences or partial sequences of Philadelphia-1, Los Angeles-1 and Micu-B3 strains of $L$. pneumophila are AF000654, AF000655 and AF000656, respectively.
}

the sole methods allowing the recognition of species. Other genotypic methods such as ribotyping (5), arbitrarily primed PCR (AP-PCR) and random amplified polymorphic DNA (RAPD) analysis have been proposed for differentiation of Legionella at the species level (13). However, ribotyping is a time-consuming method and is not suitable for routine identification of Legionella (5), while AP-PCR and RAPD are hampered by their lack of reproducibility (15). Amplification polymorphism of the intergenic $16 \mathrm{~S}-23 \mathrm{~S}$ spacer regions (ISR) have been used for identification at the species level in various genera including Legionella $(6,8,9,12,16,17)$. However, in the case of Legionella, the primers used by Hookey et al. for the ISR-PCR were targeting regions situated further away from the ISR itself, thus amplifying $400 \mathrm{nt}$ of the $16 \mathrm{~S}$ gene, resulting in larger amplicons that were harder to 
Table 1. Legionella strains tested for the 16S-23S rDNA ISR-PCR assay

Clustering as determined by ISR-PCR (after restriction when necessary). ATCC, American Type Culture Collection; NCTC, National Collection Type Culture; ${ }^{\mathrm{T}}$, type strains; ${ }^{\mathrm{L}}$, well-identified strains described in the literature. Other strains are field isolates obtained from the French Legionella Reference Centre.

\begin{tabular}{|c|c|c|c|}
\hline Species & Cluster & $\begin{array}{l}\text { No. } \\
\text { strains }\end{array}$ & Reference strains and isolates tested \\
\hline L. adelaidensis & 1 & 1 & ATCC $49625^{\mathrm{T}}$ \\
\hline L. anisa & 2 & 23 & $\begin{array}{l}\text { ATCC } 35292^{\mathrm{T}}, \mathrm{CH} 47-\mathrm{C} 3^{\mathrm{L}}, \mathrm{CH} 47-\mathrm{C1}^{\mathrm{L}} \text {, Card76A1, FoMeI-3, } \\
\text { Gene11-1, Golf1-1, Golf1-2, HD10K2, HEH15D3, } \\
\text { PaDebIH3, Stra14-14, Stra14-17, StraIX-1, StraIX-2, Stra17- } \\
\text { 5, Stra18-1, StSimI-7, Tour97I-1, Tour97I-2, Tour97I-3, } \\
\text { Tour97I-4, Cob1 }\end{array}$ \\
\hline L. birminghamensis & 3 & 3 & ATCC $43702^{\mathrm{T}}$, Aix $12 \mathrm{C} 15$, Greo8P2 \\
\hline L. bozemaniae serogroup 1 & 4 & 6 & $\begin{array}{l}\text { ATCC } 33217^{\mathrm{T}} \text {, Arizona-1 }{ }^{\mathrm{L}}, \mathrm{GAPH}^{\mathrm{L}}, \text { BruxellesD }^{\mathrm{L}} \text {, DignC61, } \\
\text { PortII-18 }\end{array}$ \\
\hline L. bozemaniae serogroup 2 & & 4 & ATCC $35545^{\mathrm{T}}$, Paris-96010250, Paris-96010251, UL-7T/2 \\
\hline L. brunensis & 5 & 1 & ATCC $43878^{\mathrm{T}}$ \\
\hline L. cherrii & 6 & 1 & ATCC $35252^{\mathrm{T}}$ \\
\hline L. cincinnatiensis & 7 & 1 & ATCC $43753^{\mathrm{T}}$ \\
\hline 'L. donaldsonii'* & 8 & 1 & $\mathrm{LC} 878$ \\
\hline L. dumoffii & 9 & 8 & $\begin{array}{l}\text { ATCC } 33279^{\mathrm{T}} \text {, ATCC } 35850^{\mathrm{L}} \text {, Aix80B3, Aix96VII2-4, } \\
\text { Aix96VII7-1, Lech2F10, Stra-92101226, Toul23-6 }\end{array}$ \\
\hline L. erythra serogroup 1 & 10 & 5 & $\begin{array}{l}\text { ATCC } 35303^{\mathrm{T}} \text {, Aix96VII2-1, AngeIVLevant, CEP3F29, } \\
\text { Toul26-20 }\end{array}$ \\
\hline L. erythra serogroup 2 & & 5 & NCTC $11987^{\mathrm{T}}$, Aix96VII2-6, Madr12-6, Stra96XXII-5, UL-13 \\
\hline L. fairfieldensis & 11 & 1 & ATCC $49588^{\mathrm{T}}$ \\
\hline L. feeleii serogroup 1 & 12 & 4 & ATCC $35072^{\mathrm{T}}$, Ly126.92a, Ly126.92b, Ly 166.96 \\
\hline L. feeleii serogroup 2 & & 1 & ATCC 35849 \\
\hline L. geestiana & 13 & 2 & ATCC $49504^{\mathrm{T}}$, ParDid16-1 \\
\hline Legionella genomospecies 1 & 14 & 1 & ATCC $51913^{\mathrm{T}}$ \\
\hline L. gormanii & 15 & 4 & ATCC $33297^{\mathrm{T}}$, Greo9C3, Greo9C5, Toul29-16 \\
\hline L. gratiana & 16 & 1 & ATCC $49413^{\mathrm{T}}$ \\
\hline L. hackeliae serogroup 1 & 17 & 1 & ATCC $35250^{\mathrm{T}}$ \\
\hline L. hackeliae serogroup 2 & 18 & 1 & ATCC 35999 \\
\hline L. israelensis & 18 & 1 & ATCC $43119^{T}$ \\
\hline L. jamestowniensis & 20 & 1 & ATCC $35298^{\mathrm{T}}$ \\
\hline L. jordanis & 21 & 3 & ATCC $33623^{\mathrm{T}}$, BesacII-1, Ly95.96 \\
\hline L. lansingensis & 22 & 1 & ATCC $49751^{\mathrm{T}}$ \\
\hline L. londiniensis serogroup 1 & 23 & 7 & $\begin{array}{l}\text { ATCC } 49505^{\mathrm{T}} \text {, CF97I-1, Frankfurt3, IP8-1, IB35-1, Gre5-1, } \\
\text { Mul12A1 }\end{array}$ \\
\hline L. londiniensis serogroup 2 & & 1 & MulhB26 \\
\hline L. longbeachae serogroup 1 & 24 & 1 & $\operatorname{ATCC} 33462^{\mathrm{T}}$ \\
\hline L. longbeachae serogroup 2 & & 1 & ATCC 33484 \\
\hline L. maceachernii† & 25 & 2 & ATCC $35300^{\mathrm{T}}$, Toul20-5 \\
\hline L. micdadei & 26 & 10 & $\begin{array}{l}\text { ATCC } 33218^{\mathrm{T}}, \text { CF97I-2, PPA }{ }^{\mathrm{L}}, \text { Virginia-1 } \\
\text { Toul29-9, PortIII10, } \\
\text { Aix 73G9, ToulonVI-5, Toul16-5, LugII124 }\end{array}$ \\
\hline L. moravica & 27 & 3 & ATCC $43877^{\mathrm{T}}$, CoimbS20, NancII-1 \\
\hline L. nautarum & 28 & 1 & ATCC $49506^{\mathrm{T}}$ \\
\hline L. oakridgensis & 29 & 13 & $\begin{array}{l}\text { ATCC } 33761^{\mathrm{T}} \text {, Aix31H1, Dign2C34, Dijo6-2, Greo8E18, } \\
\text { LillA1, Nant3, NantIV-1, NantV-2, NantV-6, Nant- } \\
\text { 930101937, Nant-93101868, PortII-16 }\end{array}$ \\
\hline L. parisiensis & 30 & 2 & ATCC $35299^{\mathrm{T}}$, ATCC $700174^{\mathrm{L}}$ \\
\hline L. quateirensis & 31 & 1 & ATCC $49507^{\mathrm{T}}$ \\
\hline
\end{tabular}


Table 1. (cont.)

\begin{tabular}{|c|c|c|c|}
\hline Species & Cluster & $\begin{array}{l}\text { No. } \\
\text { strains }\end{array}$ & Reference strains and isolates tested \\
\hline L. pneumophila & 32 & 75 & 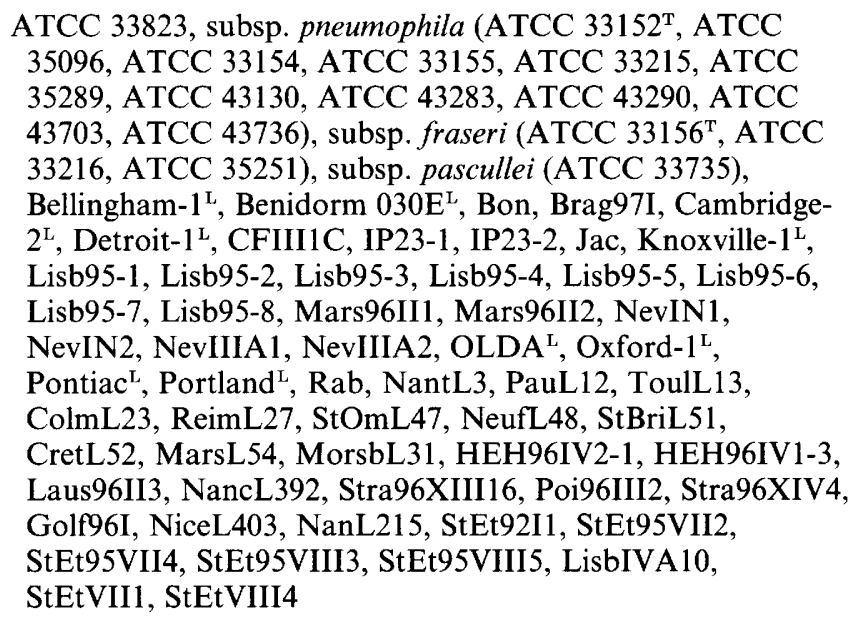 \\
\hline L. quinlivanii serogroup 1 & 33 & 8 & 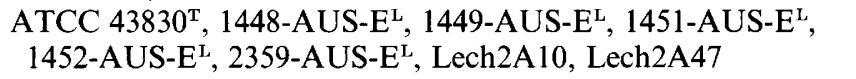 \\
\hline L. quinlivanii serogroup 2 & & 1 & NCTC 12434 \\
\hline L. rubrilucens & 34 & 48 & $\begin{array}{l}\text { ATCC 35304' , Aix56, Ango6-1, Dijo45-1, Dijo48-2, Gene2, } \\
\text { Lech2E58, VillefA1, TuriI-1, TuriI-2, Turill-180, TuriII-195, } \\
\text { Laus15-6, Gene10-1, Laus96V-1, HoDi2B3, HoDi2B4, } \\
\text { HoDi2B12, Toul26-14, C/SE1C25, C/SE1C26, GapIB41, } \\
\text { GapIB42, MoulIC1, MoulID1, MoulID6, IB39-6, Toul26- } \\
\text { 17, Toul28-7, Merc96I8-8, Merc96I8-7, HeGaIe1C7, } \\
\text { HeGae3C7, HeGae3C10, CrRo2C9, CrRo2C13, LisbIIIA5, } \\
\text { PortA12, PortA13, PortA14, PortA16, PortA17, PortA19, } \\
\text { PortA20, MadrI-4, MadrIV-1, BM-750, Toul28-8 }\end{array}$ \\
\hline L. sainthelensi serogroup 1 & 35 & 1 & ATCC $35248^{\mathrm{T}}$ \\
\hline L. sainthelensi serogroup 2 & & 1 & ATCC 49322 \\
\hline L. santicrucis & 36 & 1 & ATCC $35301^{\mathbf{T}}$ \\
\hline L. shakespearei & 37 & 1 & ATCC $49655^{T}$ \\
\hline L. spiritensis serogroup 1 & 38 & 1 & ATCC $35249^{\mathrm{T}}$ \\
\hline L. spiritensis serogroup 2 & 39 & 1 & NCTC 12082 \\
\hline L. steigerwaltii & 40 & 1 & ATCC $35302^{\mathrm{T}}$ \\
\hline L. tucsonensis & 41 & 1 & ATCC $49180^{\mathrm{T}}$ \\
\hline L. wadsworthii & 42 & 1 & ATCC $33877^{\mathbf{T}}$ \\
\hline L. waltersii & 43 & 1 & ATCC $51914^{\mathrm{T}}$ \\
\hline L. worsleiensis & 44 & 3 & ATCC 49508, SBPIB1, SBPIB2 \\
\hline Legionella sp. type 1 & 45 & 3 & Greo11D13, Mulh12A22, Mulh12A23 \\
\hline Legionella sp. type 2 & 46 & 3 & IBV-2, IBV-3, VeniIA1 \\
\hline Legionella sp. type 3 & 47 & 1 & DignB112 \\
\hline Legionella sp. type 4 & 48 & 1 & RochA21 \\
\hline Legionella sp. type 5 & 49 & 1 & HEH11G3 \\
\hline Legionella sp. type 6 & 50 & 1 & Francf3 \\
\hline Legionella sp. type 7 & 51 & 1 & Toul24-16 \\
\hline Legionella sp. type 8 & 52 & 1 & Corse13B 8 \\
\hline Legionella sp. type 9 & 53 & 1 & Toul28-5, CFVII-1 \\
\hline Legionella sp. type 10 & 54 & 1 & IP8-1 \\
\hline Legionella sp. type 11 & 55 & 2 & MadVII-1, Mad12-2 \\
\hline Legionella sp. type 12 & 56 & 1 & Nevers 101 \\
\hline Legionella sp. type 13 & 57 & 5 & MontA1, MontA2, MontA3, MontA4, MontA5 \\
\hline
\end{tabular}

* Kindly provided by T. G. Harrison (Legionella Reference Unit, Respiratory and Systematic Infection Laboratory, Central Public Health Laboratory, Colindale, London, UK).

†Validated as Tatlockia maceachernii comb. nov. [Validation List no. 38; IJSB 41, 456-457 (1991)]. 
resolve and did not provide enough discrimination to distinguish members of the bluish-white autofluorescent species of the Legionellaceae (9). In the present study, consensus primers designed from multiple alignment of $16 \mathrm{~S}$ and $23 \mathrm{~S}$ genes of diverse bacteria $(17,18)$ were tested for their ability to differentiate all Legionella species including the bluish-white autofluorescent species.

\section{METHODS}

Bacterial strains. Seventy-nine reference strains representing 42 species (including 15 Legionella pneumophila) were tested together with 212 clinical and environmental isolates obtained from the French Legionella Reference Centre (Table 1). Among these, 189 field isolates were previously tested by conventional methods (growth characteristics, biochemical reactivity and DFA with specific antisera prepared by rabbit hyperimmunization at the French Legionella Reference Centre, Lyon). The remaining 23 strains correspond to well identified strains from previous studies (Table 1). All strains were stored in liquid nitrogen until used and then cultured on BCYE agar plates (4).

Preparation of DNA templates for PCR. Chromosomal DNA templates were prepared from $72 \mathrm{~h}$ cultures on BCYE following a thermal lysis procedure (11). Nucleic acids were purified by the addition of phenol/chloroform/isoamyl alcohol (14) and precipitated by the addition of absolute ethanol. The pellet was vacuum-dried, resuspended in $200 \mu \mathrm{l}$ sterile distilled water and stored at $-20^{\circ} \mathrm{C}$ until used.

PCR amplification of intergenic 16S-23S rDNA sequences. Primers FGPS1490-72 (5'-TGCGGCTGGATCCCCTCCTT-3') (located at nucleotides 1521-1541 of the 16S rRNA gene sequence of Escherichia coli-GenBank accession no. J01695) and FGPL132'-38 (5'-CCGGGTTTCCCCATTCGG-3') (located at nucleotides 114-132 of the 23S rRNA gene sequence of $E$. coli-accession no. J01695) were designed previously from multiple alignments of $16 \mathrm{~S}$ and $23 \mathrm{~S}$ genes of diverse bacteria (18). Primer FGPS1490-72 is located three bases away from the $3^{\prime}$ end of the $16 \mathrm{~S}$ gene, and primer FGPL132'-38 is located 114 bases away from the $5^{\prime}$ end of the $23 \mathrm{~S}$ gene. These primers are complementary to the conserved regions 4 (positions $1521-1541$ for $16 \mathrm{~S}$ rRNA gene) and 6 (positions 114-132 for the 23S rRNA gene) within the rDNA operon and match the recommended positions to detect spacer variation at the species level (7). DNA templates $(5 \mu \mathrm{g}, 10 \mu \mathrm{l})$ were amplified in a $100 \mu \mathrm{l}$ reaction volume that contained $2.5 \mathrm{U}$ Taq polymerase (Perkin Elmer Cetus), $1 \mathrm{mM}$ each primer, $0.2 \mathrm{mM}$ of each of the four dNTPs (Pharmacia Biotech), $10 \mathrm{mM}$ Tris $/ \mathrm{HCl}$ (pH 8.3), $50 \mathrm{mM} \mathrm{KCl}, 1.5 \mathrm{mM} \mathrm{MgCl}_{2}$ and $0.1 \mathrm{mg}$ gelatin $\mathrm{ml}^{-1}$ (Perkin Elmer). Reaction mixtures were overlaid with $50 \mu \mathrm{l}$ mineral oil and heated to $95^{\circ} \mathrm{C}$ for $2 \mathrm{~min}$ prior to amplification. Amplification was carried out in a PHC-3 Dri-Block cycler (Techne, Cambridge, UK) for 35 cycles. Each amplification cycle was as follows: $1 \mathrm{~min}$ (denaturation) at $95^{\circ} \mathrm{C}, 1 \mathrm{~min}$ (annealing) at $55^{\circ} \mathrm{C}$, and 2 min (extension) at $72^{\circ} \mathrm{C}$. Controls were included in each set of amplifications, namely, a reaction mixture with no DNA added.

Detection of the amplification products. Following amplification, $20 \mu \mathrm{l}$ each sample was electrophoresed through $1.5 \%$ agarose gel (FMC BioProducts) in $0.5 \times \mathrm{TBE}$ buffer as described (11). Gels were then stained with ethidium bromide and photographed under UV light. DNA fragment sizes were compared with the DNA Molecular Weight Marker VI (Boehringer Mannheim). The sizing of fragments of each PCR product and the schematic representation of ISR-PCR profiles were done using the Taxotron software package (Institut Pasteur, Paris, France).

To assess PCR reproducibility, the $16 \mathrm{~S}-23 \mathrm{~S}$ rDNA intergenic spacer regions were amplified more than twice for each strain. The two separate PCR amplification mixtures prepared for each strain were run side by side as well as on different gels. To calculate the lengths of amplicons, a DNA molecular size marker was included. The gels were photographed and scanned. The lengths of PCR products were calculated automatically by using the RestrictoScan and RestrictoTyper programs (P. A. D. Grimont, Taxolab, Institut Pasteur, Paris, France), and mean sizes (standard deviations) were calculated for each strain.

PCR-RFLP analysis. When necessary, amplicon DNA without any further purification step was restricted with HinfI (Appligene) for $1 \mathrm{~h}$ at $37^{\circ} \mathrm{C}$. The digested products were then resolved on a $3 \%(\mathrm{w} / \mathrm{v})$ agarose gel.

DNA sequencing of the $16 \mathrm{~S}-235$ spacers regions. DNA sequencing was performed on the $450 \mathrm{bp}$ purified PCR products from $L$. pneumophila subsp. pneumophila strain Philadelphia-1, L. pneumophila subsp. fraseri strain Los Angeles-1 and L. pneumophila subsp. pascullei strain MicuB3. After agarose gel electrophoresis, DNA bands were excised from the gel and purified using the Geneclean Kit II (Bio101). Automated DNA sequencing of the purified DNA was performed on an Applied Biosystems 373A sequencer by a commercial company (Genome Express)

DNA sequences were analysed and compared in the DDBJ/ EMBL/GenBank databases with the BLAST program (1).

\section{RESULTS}

The strategy of evaluation of the ISR-PCR method as a taxonomic tool for the Legionellaceae was as follows: (i) use on reference strains; (ii) use on isolates identified by DFA typing; and (iii) use on atypical strains not clearly assigned to a known taxon.

Legionella reference strains displayed various PCR profiles (Fig. 1) made of 1-6 bands with sizes ranging from 330 to $1080 \mathrm{bp}$, which is consistent with the expected length of the $16 \mathrm{~S}-23 \mathrm{~S}$ intergenic region of members of the Proteobacteria (18). However, to eliminate the possibility that the shortest PCR products, due to their small size, could correspond to intragenic rDNA, these products were sequenced for three strains of $L$. pneumophila, namely $L$. pneumophila subsp. pneumophila Philadelphia-1 strain (ATCC $\left.33152^{\mathrm{T}}\right)$, L. pneumophila subsp. fraseri Los Angeles-1 (ATCC $33156^{\mathrm{T}}$ ) and L. pneumophila subsp. pascullei Micu-B3 (ATCC $33735^{\mathrm{T}}$ ). No significant differences in composition were seen between the three sequences that were highly homologous to the ISR of numerous members of the alpha and gamma subclasses of the Proteobacteria. For instance, the sequence of the $L$. pneumophila subsp. fraseri 16S-23S spacer region had $86 \%$ homology with that of Pseudomonas stutzeri (GenBank accession no. U65012). Additionally, as expected for ISR DNA, some of these sequences contained highly conserved tRNA ${ }^{\text {ala }}$ gene. 


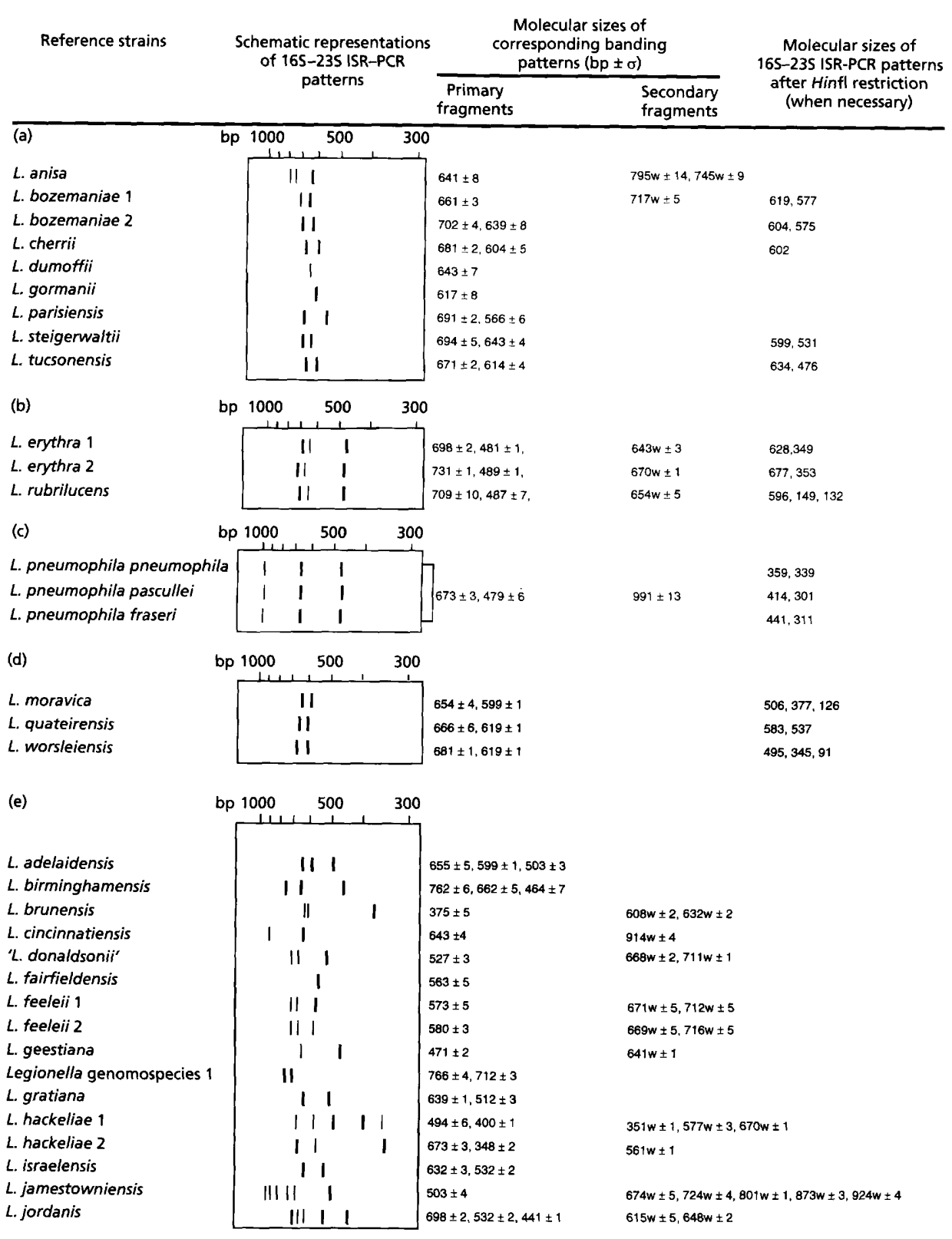

(f)

L. lansingensis

L. Iondiniensis

L. longbeachae 1

L. longbeachae 2

L. maceachernii

L. micdadei

L. nautarum

L. oakridgensis

L. quinlivanii 1

L. quinlivanii 2

L. sainthelensi 1

L. sainthelensi 2

L. santicrucis

L. shakespearei

L. spiritensis 1

L. spiritensis 2

L. wadsworthii

L. waltersii

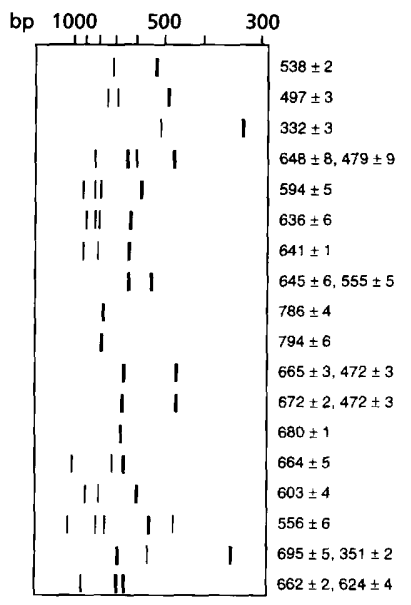

$719 w \pm 1$

$753 w \pm 3,696 w \pm 7$

$515 w \pm 5$

$837 w \pm 3,602 w \pm 2$

$933 w \pm 4,843 w \pm 4,797 w \pm 3$

$904 w \pm 4,842 w \pm 2,803 w \pm 4$

$928 w \pm 2,821 w \pm 2$

$1043 w \pm 3,724 w \pm 4$

$912 w \pm 3,801 w \pm 2$

$1081 w \pm 1,823 w \pm 4,765 w \pm 5,476 w \pm 6$

$556 w \pm 6$

$861 w \pm 2$
Fig. 1. Intergenic 16S-235 amplification patterns of Legionella strains. Left, reference strains and schematic representations of 16S-235 ISR-PCR patterns drawn with the Taxotron software package; middle, molecular sizes and inter-gel standard errors $(\sigma)$ of primary and secondary fragments of ISRPCR; right, molecular sizes of ISR-PCR products after Hinfl restriction. Strains were disposed according to phylogenic groups for the bluish-white autofluorescent species (a), the red autofluorescent species (b), the $L$. pneumophila group (c), or on the basis of closely related ISR-PCR profiles (d), and by alphabetical order for the remaining species $(e, f)$. 


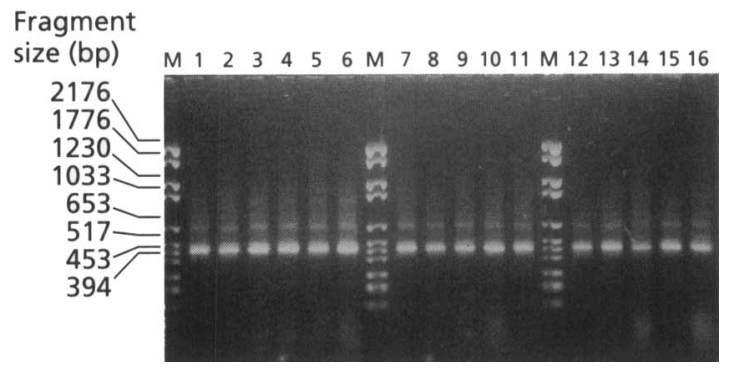

Fig. 2. Agarose gel electrophoresis of PCR-amplified 16S-23S rDNA spacer regions from Legionella pneumophila strains. Lanes: $M$, molecular size markers; 1 , subsp. pneumophila ATCC 43130; 2, subsp. pneumophila ATCC 43290; 3, subsp. pneumophila ATCC 43736; 4, subsp. pneumophila ATCC 43703; 5, subsp. fraseri ATCC 35251; 6, subsp. pascullei ATCC 33735; 7 , subsp. pneumophila ATCC 33215; 8, ATCC 33823; 9, subsp. pneumophila ATCC 35096; 10, subsp. pneumophila ATCC 35289; 11, subsp. pneumophila ATCC 43283; 12, subsp. pneumophila ATCC $33152^{\top}$; 13 , subsp. pneumophila ATCC 33154; 14, subsp. pneumophila ATCC 33155; 15, subsp. fraseri ATCC $33156^{\top} ; 16$, subsp. fraseri ATCC 33216.

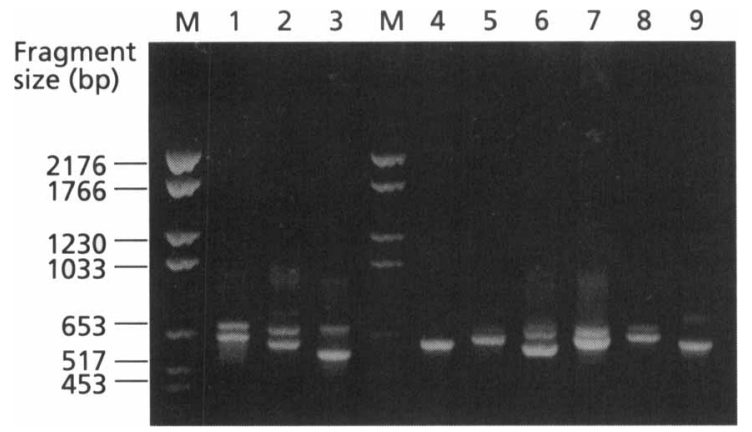

Fig. 3. Agarose gel electrophoresis of PCR-amplified 16S-23S rDNA spacer regions from type and reference strains of bluishwhite autofluorescent species. Lanes: $M$, molecular size marker; 1, L. anisa ATCC $35292^{\top} ; 2$, L. bozemaniae serogroup 1 ATCC $33217^{\top}$; 3, L. bozemaniae serogroup 2 ATCC $35545 ; 4$, L. cherrii ATCC $35252^{\top} ; 5, L$. dumoffii ATCC $33279^{\top} ; 6$, L. gormanii ATCC $33297^{\top} ; 7$, L. parisiensis ATCC 35299 ${ }^{\top}$; 8, L. tucsonensis ATCC $49180^{\top} ; 9$, L. steigerwaltii ATCC $35302^{\top}$.

The patterns of the reference strains were compared visually and also by calculating the molecular size of each band. The abundant fragments are referred to as primary products, and the weaker ones are referred to as secondary products (Fig. 1). The mean estimated molecular sizes and standard errors were calculated from repeated inter-gel ISR profiles of each reference strain. A maximum difference of $14 \mathrm{bp}$ ( $L$. anisa secondary fragment) leads us to conclude that the level of uncertainty in the calculated sizes of amplification products did not exceed $2-2 \cdot 5 \%$.

Thirty-four type and reference strains showed distinctive ISR-PCR profiles. L. pneumophila showed a species-specific profile that was identical for the 15 serogroups (Fig. 2). In several cases, such as the bluish-

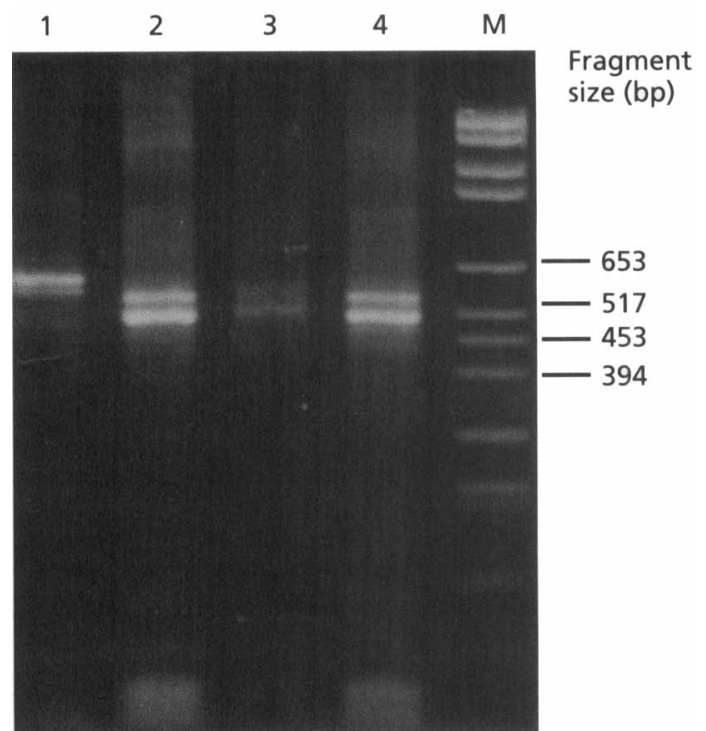

Fig. 4. Agarose gel electrophoresis of PCR-amplified 16S-23S rDNA spacer regions from Legionella bozemaniae and Legionella steigerwaltii strains after Hinfl digestion. Lanes: $M$, molecular size marker; $1, L$. bozemaniae serogroup 2 ATCC $35545 ; 2-4$, multiple amplicons of $L$. steigerwaltii ATCC $35302^{\top}$.

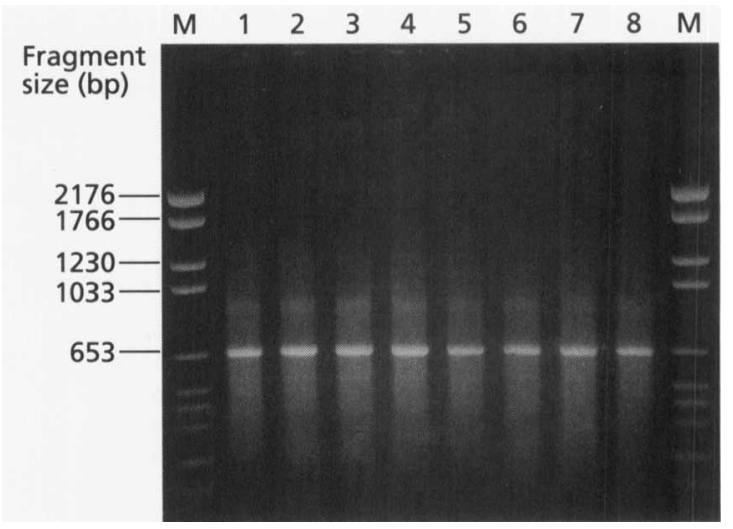

Fig. 5. Agarose gel electrophoresis of PCR-amplified 16S-23S rDNA spacer regions from non-epidemiologically related Legionella dumoffii strains. Lanes: $M$, molecular size marker; 1 , ATCC $33279^{\mathrm{T}}$; 2, ATCC 35850; 3, Aix80B3; 4, Aix96VII2-4; 5, Aix96VII7-1; 6, Lech2F10; 7, Stra-92101226; 8, Toul23-6.

white autofluorescent group, ISR-PCR profiles corresponding to different species or subspecies were either strictly identical or closely related, i.e. within the range of standard error of fragment size (Fig. 3, lanes 1 and 7). In such cases, the profiles were differentiated after HinfI restriction digest of the PCR products (Figs 1 and 4).

One hundred and thirty-two isolates identified previously by DFA (including 23 strains from the literature) belonging to 18 species were tested. ISR-PCR profiles obtained for each of these isolates were either 
strictly identical or closely related, i.e. within the range of standard error of fragment size, to those obtained for the type strains (see Fig. 5, which shows the example of Legionella dumoffii). Although Legionella longbeachae and Legionella spiritensis ISR-PCR patterns are not, strictly speaking, species-specific (Fig. 1), the majority of the other species tested showed no strain-to-strain variations (Figs 2 and 5). However, intraspecies variations cannot be excluded for the species for which only the type strains were available.

The ability of ISR-PCR to identify phenotypically aberrant strains of Legionella was tested on 80 field isolates which were not formally identified at the species level on the basis of major cross-reactions using the DFA assay and/or atypical biochemical characteristics. These isolates mostly belonged to the bluishwhite autofluorescent group. Fifty-seven per cent $(46 / 80)$ of these isolates showed profiles identical to that of a type or reference strain for which a crossreaction was observed by DFA. In $42 \%$ of cases $(34 / 80)$, results of ISR-PCR differed from those of DFA. Of these, 12 strains showed ISR profiles that did not correspond to those of the type strains which gave cross-reaction by DFA, and 22 strains showed ISR profiles unrelated to any of the known profiles. These unidentified strains may correspond either to new species or subspecies or to a subtype within a given species.

\section{DISCUSSION}

Species identification of Legionella based on phenotypic traits is time-consuming and restricted to specialized laboratories. In the present study, we show that intergenic ribosomal PCR is a rapid (less than $2 \mathrm{~d}$ ) and efficient tool for identification of the Legionella at the species and subspecies levels. Our results differed from a comparable study conducted by Hookey et al. (9) by the sizes of the amplified products and in some cases by the number of bands in the profiles. The primers choosen in the present study from regions 4 (positions 1521-1541 for the 16S rRNA gene) and 6 (positions 114-132 for the 23S rRNA gene) within the rDNA operon (7) were much closer to the ISR itself, and not surprisingly were successful in detecting spacer variation even between the bluish-white autofluorescent species (Fig. 1a) and the red autofluorescent species (Fig. 1b) which are otherwise difficult to identify. By designing primers that match nucleotides 1113-1130 of the 16S rDNA, Hookey and co-workers have amplified fragments that were longer by nearly $400 \mathrm{bp}$, resulting in decreased efficiency to detect spacer variation by standard agarose gel electrophoresis. For instance, we were able to reveal subtle differences between size fragments of Legionella cherrii $(681 \pm 2$ and $604 \pm 2 \mathrm{bp}$ ) and Legionella tucsonensis (671 \pm 2 and $614 \pm 4 \mathrm{bp}$ ) (Fig. 1a), which were not resolved between fragments in the size range of 1100 and $1200 \mathrm{bp}$ in Hookey's study (9). Analysis of the RFLP generated after HinfI restriction digestion of the
PCR products further improved the discrimination between species or subspecies (Figs 1 and 4). Hence, $L$. pneumophila subsp. pneumophila showed profiles that were distinct from those of $L$. pneumophila subsp. fraseri and L. pneumophila subsp. pascullei (Fig. 1c). Such discrimination can otherwise be only obtained by time-consuming methods such as DNA-DNA hybridization (3), or whole-cell protein SDS-PAGE (20).

Importantly, intraspecies stability of ISR-PCR profile was demonstrated for a number of species by showing that multiple well-identified isolates of a given species showed an identical pattern to that of the reference and type strains (shown in Fig. 2 for L. pneumophila and in Fig. 5 for $L$. dumoffii). In this matter, determination of fragment sizes and standard errors for each ISR-PCR pattern provided a convenient way of comparing patterns, since the level of uncertainty in the calculated sizes of amplification products did not exceed $2-2 \cdot 5 \%$. ISR-PCR was also able to identify a collection of phenotypically aberrant Legionella isolates at the species level. In most cases, the species assignment by ISR-PCR was within the group of species for which cross-reactions were observed by DFA. This confirms the usefulness of the method in cases where definite identification cannot be easily obtained by conventional methods. However, a number of strains remained unidentified by this approach and may correspond to new taxa; these strains will be further characterized by DNA-DNA hybridization and $16 \mathrm{~S}$ rRNA gene sequencing.

\section{ACKNOWLEDGEMENTS}

We wish to thank F. Renaud for scientific advice, and C. Bouveyron, P. Lefevre, C. Vallier, D. de Longevialle and M. Siffert for technical support.

\section{REFERENCES}

1. Altschul, S. F., Gish, W., Miller, W., Myers, E. W. \& Lipman, D. J. (1990). Basic local alignment search tool. $J$ Mol Biol 215, $404-410$.

2. Benson, R. F., Thacker, W. L., Daneshvar, M. I. \& Brenner, D. J. (1996). Legionella waltersii sp. nov. and an unnamed Legionella genomospecies isolated from water in Australia. Int J Syst Bacteriol 46, 631-634.

3. Brenner, D. J. (1986). Classification of Legionellaceae. Current status and remaining questions. Isr J Med Sci $\mathbf{2 2}$, 620-632.

4. Edelstein, P. H. (1981). Improved semiselective medium for isolation of Legionella pneumophila from contaminated clinical and environmental specimens. J Clin Microbiol 14, 294-303.

5. Grimont, F., Lefèvre, M., Ageron, E. \& Grimont, P. A. D. (1989). rRNA gene restriction patterns of Legionella species: a molecular identification system. Res Microbiol 140, 615-626.

6. Gürtler, V. \& Barrie, H. D. (1995). Typing of Staphylococcus aureus strains by PCR-amplification of variable-length 16S-23S rDNA spacer regions: characterization of spacer sequences. Microbiology 141, 1255-1265. 
7. Gurtler, V. \& Stanisich, V. A. (1996). New approaches to typing and identification of bacteria using the $16 \mathrm{~S}-23 \mathrm{~S}$ rDNA spacer region. Microbiology 142, 3-16.

8. Harrell, L. J., Andersen, G. L. \& Wilson, K. H. (1995). Genetic variability of Bacillus anthracis and related species. $J$ Clin Microbiol 33, 1847-1850.

9. Hookey, J. V., Birtles, R. J. \& Saunders, N. A. (1995). Intergenic 16S rRNA gene (rDNA)-23S rDNA sequence length polymorphisms in members of the family Legionellaceae. $J$ Clin Microbiol 33, 2377-2381.

10. Hookey, J. V., Saunders, N. A., Fry, N. K., Birtles, R. J. \& Harrison, T. G. (1996). Phylogeny of Legionellaceae based on small-subunit ribosomal DNA sequences and proposal of Legionella lytica comb. nov. for Legionella-like amoebal pathogens. Int $J$ Syst Bacteriol 46, 526-531.

11. Jaulhac, B., Nowicki, M., Bornstein, N., Meunier, O., Prevost, G., Piemont, Y., Fleurette, J. \& Monteil, H. (1992). Detection of Legionella spp in bronchoalveolar lavage fluids by DNA amplification. J Clin Microbiol 30, 920-924.

12. Jensen, M. A., Webster, J. A. \& Straus, N. (1993). Rapid identification of bacteria on the basis of polymerase chain reaction-amplified ribosomal DNA spacer polymorphisms. Appl Environ Microbiol 59, 945-952.

13. Lo Presti, F., Riffard, S., Vandenesch, F., Reyrolle, M., Ronco, E., Ichai, P. \& Etienne, J. (1997). The first clinical isolate of Legionella parisiensis, from a liver transplant patient with pneumonia. J Clin Microbiol 35, 1706-1709.
14. Marmur, J. (1961). A procedure for the isolation of deoxyribonucleic acid from microorganisms. $J \mathrm{Mol}$ Biol 3, 208-218.

15. Meunier, J. R. \& Grimont, P. A. D. (1993). Factors affecting reproducibility of random amplified polymorphic DNA fingerprinting. Res Microbiol 144, 373-379.

16. Navarro, E., Simonet, P., Normand, P. \& Bardin, R. (1992). Characterization of natural populations of Nitrobacter spp. using PCR/RFLP analysis of the ribosomal intergenic spacer. Arch Microbiol 157, 107-115.

17. Normand, P., Cournoyer, B., Nazaret, S. \& Simonet, P. (1992). Analysis of a ribosomal RNA operon in the actinomycete Frankia. Gene 111, 119-124.

18. Normand, P., Ponsonnet, C., Nesme, X., Neyra, M. \& Simonet, P. (1996). ITS analysis of prokaryotes. In Molecular Microbial Ecology Manual, pp. 1-12. Edited by A. D. L. Akkermans, J. D. van Elsas \& F. J. De Bruijn. Dordrecht, The Netherlands: Kluwer.

19. Rodgers, F. G. \& Pasculle, A. W. (1991). Legionella. In Manual of Clinical Microbiology, 5th edn, pp. 442-453. Edited by A. Balows, W. J. Hausler, Jr, K. L. Herrmann, H. D. Isenberg \& H. J. Shadomy. Washington, DC: American Society for Microbiology.

20. Verissimo, A., Morais, P. V., Diogo, A., Gomes, C. \& Costa, M. S. D. (1996). Characterization of Legionella species by numerical analysis of whole-cell protein electrophoresis. Int $J$ Syst Bacteriol 46, 41-49. 